\title{
From fur to fir: Lessons for the BC forest industry from the anti-fur campaign
}

\author{
by Heather Myers ${ }^{1}$
}

\begin{abstract}
BC's forest industry is feeling internal and international pressure to change its practices, and there is an increasing move to certification, amidst debates about preferred certification modes. This reflects changes in the economies of many of Canada's rural and northern communities, which have traditionally been dependent upon natural resources, but are now coming under pressure from the global community - not only in economic terms, but in terms of social values. As demography changes, and with it, social and economic values, this pressure is likely to continue. The Canadian North first felt such pressure as a result of the European boycott of the Newfoundland seal hunt, and then anti-trapping boycotts that have occurred periodically since then. These campaigns have had a profound effect on the lifestyles, cultures and sustainability of the northern communities. Over almost three decades, the government, non-government organizations and people of the North have had to learn to deal with and respond to these external campaigns that threaten them. The lessons they have learned about the nature of these campaigns could be useful to the province of British Columbia, which is now coming under increasing pressure from Europe and the US regarding its forestry practices. This paper outlines the evolution and characteristics of the international campaigns against sealing and trapping, as well as the experiences of northerners in dealing with them. It goes on to apply these lessons to the BC situation, with some recommendations for appropriate responses. Fundamentally, these campaigns reflect changing demographic and social characteristics and values in North America and Europe, and the changing relationship of people to natural resources, but they also raise questions about fair reflection of the variety of stakeholder interests in resource decision-making, and the limits on definition of "stakeholders."
\end{abstract}

\section{Key words: Boycotts, resource use}

L'industrie forestière de la Colombie-Britannique ressent des pressions internes et internationales qui cherchent à modifier ses pratiques, en plus d'une tendance croissante vers la certification qui s'effectue parmi des débats sur les modes de certification préférés. Cela reflète les changements survenus dans l'économie de plusieurs communautés rurales et nordiques du Canada, qui ont traditionnellement dépendantes des ressources naturelles, mais qui sont maintenant sous pression de la part de la part de la communauté mondiale - non seulement en termes économiques, mais également en terme de valeurs sociales. Les modifications démographiques, et avec elles, la modification des valeurs sociales et économiques, devraient vraisemblablement se poursuivent. Le nord du Canada a connu le premier une telle pression suite au boycottage européen de la chasse au phoque à Terre-Neuve, et puis par les boycottages anti-trappage qui ont été organisé périodiquement depuis ce moment. Ces campagnes ont eu de profondes répercussions sur le mode de vie, la culture et la durabilité des communautés nordiques. Au cours de presque de trois décennies, le gouvernement, les organismes non-gouvernementaux et les gens du Nord ont dû apprendre à faire face à ces campagnes extérieures qui les menaçaient et à y répondre. Les leçons qui ont été tirées de la nature de ces campagnes pourraient être utiles à la province de la Colombie-Britannique, qui fait maintenant l'objet de pressions croissantes en provenance de l'Europe et des États-Unis relativement à ses pratiques forestières. Cet article souligne l'évolution et les caractéristiques des campagnes internationales contre la chasse au phoque et le trappage, ainsi que l'expérience acquise par les gens du Nord. Il se poursuit sur l'application des ces leçons dans le contexte de la Colombie-Britannique, en ajoutant des recommandations pour obtenir des réponses adéquates. Fondamentalement, ces campagnes reflètent le changement survenu dans les caractéristiques démographiques et sociales en Amérique du Nord et en Europe, ainsi que la modification des relations entretenues par les gens envers les ressources naturelles, mais elles soulèvent également des questions au sujet de la représentativité adéquate de la variété d'intérêts des personnes impliquées dans le processus de décision de la gestion des ressources, et des limites de la ressource, et des « intervenants ».

\section{Introduction}

$\mathrm{BC}$ and other forest producers are rapidly coming to grips with eco-certification as a way to protect their markets and viability, after many years of anti-logging campaigns. While certification may help to improve forest practices, it must still be evaluated critically, to ensure that it will be effective in achieving sustainable development. Viewed from a historical context, and earlier anti-harvest campaigns, the current antilogging campaigns raise some unsettling comparisons. The campaigns reflect fundamentally different cultural values, but real, sustainable resolution of the resource issues must rest upon

\footnotetext{
${ }^{1}$ International Studies Program, University of Northern British Columbia, Prince George, BC V2N 4Z9.
}

respect for regional differences and realities.

International campaigns, reflecting different attitudes to resources, have aimed at stopping several Canadian resource uses - sealing, trapping, and now logging. Yet, many Canadians are deeply rooted in economic and cultural systems that are linked to use, stewardship and enjoyment of

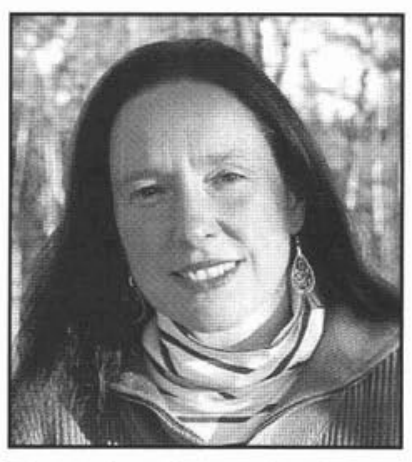
the rich Canadian resource base. The anti-sealing and anti-trapping campaigns struck at the very economy, culture and identity of northern peoples, and at what was a sustainably man- 
aged, renewable lifestyle. Now, British Columbia (BC) forestry is receiving international attention regarding its forestry practices, including anti-logging campaigns and market boycotts. There is a lot to be learned from the experiences of the NWT, which should help to inform BC's actions in response to the anti-logging movements. As the demographic characteristics in North America continue to change, along with changes in the global economy, we can expect continuing critical attention to peoples' relationships with resources in the future.

\section{The Anti-Harvest Movement and Its Effect in Northern Canada}

Canada's northern native communities have always had an economy, whether measured in dollars or in food and materials, which depended upon the wildlife, fish and other resources of the land. Even today, most northern native households have at least one harvester, and estimates of their production range from a replacement value of $\$ 10000$ (Ames et al. 1988) to $\$ 20000$ (Fast and Berkes 1994) for the food and materials used by their households. For the NWT, the value of country food consumed by aboriginal households in 1988 was estimated to be $\$ 55 \mathrm{M}$ (Ames et al. 1988). Domestic production accounts for $30-60 \%$ of all income in aboriginal communities, and up to $80 \%$ of food consumed in some aboriginal communities (Elias 1993). Beyond this economic value, the native cultures are intensely intertwined with their lands and the resources of their lands (Usher 1981): from the names given to children, to the sharing patterns that cement social networks, to the pride and status given to good hunters and processors, participation in hunting, fishing and trapping are deeply valued and integrated in northern peoples' lives.

In the late 1960s and early 1970s, Greenpeace and the International Fund for Animal Welfare took aim at the Newfoundland seal hunt, which they deemed to be ecologically unsound, and cruel. We will not examine the Newfoundland hunt any more here except to say that there were millions of seals and no ecological problem with the hunt at the size that it was. Faced with scientific proof of the large size of the seal population, the anti-sealing groups changed the debate to focus on the method of killing seals by clubbing as cruel. Ironically, years later, further proof suggested that this method was actually very humane. The most important point is that the issue of cruelty had emerged upon the field of public discourse, and it became the most important part of the seal hunt issue, and a powerfully emotional one.

In the NWT, where the Inuit had a thriving and very sustainable economy based upon the use of seals for food, oil and skins, seals were hunted differently - by rifle and harpoon, taking great skill and patience. Nonetheless, the Inuit sealskin economy was gutted by the anti-sealing campaign - self-supporting communities were reduced to welfare dependency, with a staggering suicide rate, as people seriously questioned themselves and their culture in the face of condemnation by a modern, dominant, more powerful society in southern North America and Europe (Wenzel 1991, Lynge 1992, Freeman 1997).

The next target, some years later, was the trapping industry, and again the issue was nominally ecological ${ }^{2}$, but mainly about perceptions of cruelty. Much larger than the sealskin

${ }^{2}$ No species of fur-bearer in Canada is currently threatened or endangered. issue, the anti-trapping issue affected 100000 native $^{3}$ and nonnative wild-fur trappers and their families across Canada, not to mention thousands more in secondary and tertiary sectors. In 1991, wild fur production in Canada was valued at $\$ 50-100 \mathrm{M} ; 75 \%$ of this is traditionally exported to Europe as raw pelts or finished goods (Canada, House of Commons 1993). Despite the size of the industry, it received variable attention or effort from the federal government, whose attempts at protecting the industry were often lukewarm at best. The federal government had an office dedicated to the issue, but often seemed reluctant to make strong overt statements in favour of the fur industry, though they became more active on this issue in the early 1990s. To compensate for this, the Government of the Northwest Territories (GNWT) and other provinces and organizations like the Fur Institute of Canada and Indigenous Survival International, responded actively to the anti-trapping movement's effects on northern peoples.

The anti-fur campaigns have had a serious negative impact on the fur trade in the NWT and Canada, though the markets have recently revived again after a long depression: unmanufactured fur sales peaked at around $\$ 800 \mathrm{M}$ in the mid1980 s in Canada, and dropped as low as $\$ 350 \mathrm{M}$ by 1988 , but they had climbed back to $\$ 450 \mathrm{M}$ by 1996 (Habib 1997). On a national scale, this may seem small, but to the native and nonnative trappers, who often have little other opportunity for cashgenerating employment, this cash infusion is critical to selfsufficiency. Fundamentally, the anti-fur campaigns struck at northern native peoples' self-esteem, self-image within the dominant non-native culture, and also their economic self-sufficiency. According to Michael Kendu of the Sea Shepherd Society, "if a few people are hurt for the good of the global society, then that's not our problem. It happens all the time" (Nunatsiaq News 1997).

A key tactic of the anti-sealing and anti-trapping efforts was to portray resource harvesters in as negative a light as possible - they were living archaic, rough lifestyles unsuited to the modern world. Fur use was portrayed as cruel, ignorant, frivolous, destructive, archaic, gruesome and stupid. The anti-fur campaigns' targets have evolved somewhat, over time, but now include consumers, embodied in ads such as the Lynx organization's billboards in England, showing a woman dragging a fur coat along behind her, which is smearing blood as it goes. The slogan reads: "It takes up to 40 dumb animals to make a fur coat. But only one to wear it."

Campaigns against trapping have occurred periodically since the 1970s. Indeed, Stephen Best, of the International Fund for Animal Welfare, has made it clear that his group has to mount campaigns to meet the costs of their organization as well as their goals, and that they will continue to mount campaigns, adding new ones when needed to re-stimulate the flow of donations. At a meeting in Edmonton, he spelled out his organization's agenda: first sealing, then trapping; then hunting, animal-based research, meat eating, and pet owning.

The Government of the Northwest Territories attempted to deal with some of these problems of information, interpretation, and cross-cultural understanding, as posed by the antitrapping campaigns using three important tactics.

Europeans were lobbied in Brussels, London, and other European cities, but it was also found to be very effective to bring

373000 Aboriginal adults and their families (Maracle n.d.). 
them over to the Northwest Territories, preferably in winter, in order that they could visit a trapper on a trap-line, and see first hand that these people were not blood-thirsty pillagers of the land and wildlife, and that, in fact, they worked in a thoughtful, humane and sustainable way to use a renewable resource. This worked well with those who came over, but it did not seem to have broad or guaranteed effect back in Europe.

Finally, the GNWT, through education and new trap subsidies, assisted northern trappers to make the switch to traps that are more humane. The trappers, having felt the impacts of dropping fur prices, and seen the effects of a ban on the sealhunting Inuit, had no alternative to the new traps, even though they imposed high costs on people who were not making much income to begin with. The trappers were further concerned by the fact that the new traps were bulkier, heavier, and much more dangerous to set. It seemed that humaneness for animals was to be achieved at the cost of threats to humans.

These tactics may have helped hold back a full tide of European anti-harvesting pressures, but the pressures have continued to exist nonetheless, and to resurface periodically. In the most recent round of anti-trapping pressures, the European Community (EC) proposed a ban, in 1991, on the import of furs caught in leg-hold traps ${ }^{4}$, which would come into effect in 1995. Canada and Russia, with some input from the USA, fought this regulation together, as a regional group that exports much of the fur to Europe. The ban was indeed delayed for a few years as a result. Canada threatened to take the issue to the World Trade Organization, confident that it would be found to contravene principles of the General Agreeİment on Tariffs and Trade. Realizing the potential for embarent, Sir Leon Britten, head of the EC at the time, began talks with the Canadian and US trade ministers in 1994. In 1995, The promised that the Community would develop amend¿tion for one year (Fleck, S., Department of Renewable Tosources, GNWT, Yellowknife, personal communication, 1996).

It is ironic that $75 \%$ of the global fur market is in Europe, which makes one wonder whether the EC is listening to its public. Likewise, Justice Malouf's Royal Commission on the seal hunt in Canada found, as did a focus group in the early 1990s, that $75 \%$ of the public in Canada support trapping and sealing, and would continue to do so as long as the harvest were sustainable and as humane as possible (ICC 1996; I. Ross, Department of Renewable Resources, GNWT, Yellowknife, personal communication, 1996.). An added irony is that one can still buy leg-hold traps in Europe, where they are used to catch muskrats and other small fur-bearers - considered to be "pests" there.

Since 1968, a lot of effort has been put into designing humane traps, resulting in the world's most advanced program of trap research, development and trapper education. This has involved the Canadian Federation of Humane Societies, the Canadian Association for Humane Trapping, a FederalProvincial Committee for Humane Trapping, and the Fur Institute of Canada. A research centre at Vegreville, Alberta worked for years to design new traps and a committee of sci-

${ }^{4}$ Ironically, the ban was not justified, in the end, on the basis of animal welfare, but on the basis of management concerns for "threatened or endangered species of wild fauna"; the rationale for the regulation never mentions cruelty. entists, trappers, and animal rights advocates met for years to agree upon standards for humaneness.

Unfortunately, it became evident that whenever new traps could be designed to meet the new humane standards, the goal posts would be moved, so that the traps were not "humane enough." Likewise, the process of establishing humaneness standards and a certification process through the International Standards Organization (ISO), which started in 1989, was undermined by the activities of anti-trapping interest groups and their manipulation of nations' positions. This technique has been used at meetings of the Convention on International Trade in Endangered Species and the International Whaling Commission to manipulate votes in the direction desired by non-governmental organizations ${ }^{5}$ (Freeman 1990, Stoett 1997, p. 96). Like the humane-standards exercise in Canada, it seemed that there was no such thing as "humane enough." Whenever the Eurogroup for Animal Welfare representatives on the ISO committee would agree on a set of standards for animal welfare, they would be removed by their organizations and replaced with stronger advocates (I. Ross, Department of Renewable Resources, GNWT, Yellowknife, personal communication, 1996; F. Rossouw, Department of Resources, Wildlife and Economic Development, GNWT, Yellowknife, personal communication, 1999.). A public campaign was initiated by anti-trapping groups to discredit the ISO work, demanding that the word "humane" be taken out of the title of the Standard.

Canada, the USA, Russia and the EC met to develop a framework agreement about humane standards that the EC could agree to. Though the amendments to the proposed new European regulations were detested and resisted by some committees within the European Community and Parliament, they were eventually passed on to the Council of Environment Ministers in December 1996, and approved.

The framework agreement is set out species-by-species now, whereas the proposed ban had been a blanket one. As it turns out, not many Canadian species go to European markets - we catch few badgers or wolves for the European market, and do not send otter furs there. Only those few species that do go to Europe need to comply with the new rules. In another irony, fox and mink, which we do send, are not on the new list, because they are ranched in Europe. The new framework agreement requires that steel-jawed leg-hold traps be banned over the next four years for lynx, wolf, bobcat, racoon and coyote, but the parties can still use soft-catch traps. Leg-hold traps are still permitted for beaver, in order to achieve a three-minute humane kill standard.

Trappers in the NWT have made the switch to humane traps, and the GNWT continues to test new humane traps, anticipating a further "ratcheting-up" of standards in the future. Interest-

\footnotetext{
${ }^{5}$ To achieve a moratorium on whaling at the IWC, a three-quarters majority of voting member support was required; this was missing at first. Anti-whaling groups and environmental non-governmental organizations recruited new member governments to the IWC who would support whale conservation or a moratorium. The IWC membership was 14 to 17 countries until 1973, then it mushroomed to twice that in 1981, and about 40 by 1985 . Most of these countries did not hunt whales, and they did not necessarily even have coastlines! Membership had its benefits: with the NGOs there as observers, to report on governments' behaviours back at home, those governments with shaky environmental practices at home could score points by voting against whaling at the IWC.
} 
ingly, the USA has refused to go along with the new framework agreement, and has put little effort into helping its trapping industry to adjust, citing limitations in the American constitution, which requires all 50 states to acquiesce. The US negotiated a parallel "set of principles" in 1998 that they maintain is not legally binding (J. Stone, Department of Foreign Affairs and International Trade, Ottawa, personal communication, 2000).

This history shows the evolution of the anti-trapping campaigns: thwarted by the absence of proof of endangerment of animal populations, the campaign then focussed on "cruelty" and fundamentally different values about whether hunting or trapping are moribund activities in the "modern" world. Ironically, the rationale for the most recent EC ban seems to have brought the argument around to endangerment again, which is not justified, given animal population levels. This history also shows that the campaign will not go away - it keeps being reactivated. Anti-trapping groups have focussed on closing trade doors to furs, both by supporting government regulation, and trying to influence consumers. They have protested international processes, and intervened overtly or covertly where possible. The effect has been to damage a regional economy and society, imposing economic and cultural hardship.

\section{Public Attitudes to Logging in BC}

As with the northern communities and their reliance on hunting and trapping, many $\mathrm{BC}$ communities rely on the forest industry. People there have deep traditional, historical, social, cultural and economic ties to forestry and the land. The government of $\mathrm{BC}$ relies on the approximately $\$ 4.2 \mathrm{~B}$ in direct taxes from forestry (Hunter 1998) to fund its array of social and other programs. Now, the resource industry admits to feeling the effects of various anti-logging campaigns, though the forest companies will not, or cannot specify how much impact they have felt (D. Morrell, International Section, Ministry of Forests, Victoria, personal communication, 1999). A Price Waterhouse report found the industry lost $\$ 192 \mathrm{M}$ in 1997 , much of it related to the high costs of operating in $\mathrm{BC}$, and living up to the Forest Practices Code (BC government's answer to environmental criticism of BC logging), which has cost the industry between $\$ 750 \mathrm{M}$ and \$1B per year in additional costs (Hunter 1998). It is hard to measure sales not made, but Macmillan Bloedel's ban on clearcutting in the summer of 1998, signals an attempt to meet the demands of the "new" markets. As well, there is clearly an increasing interest in forest certification among BC operations.

Tactics used in BC's war in the forest have included blockades, spiking of trees and other sabotage, sit-ins at stores selling $\mathrm{BC}$ old-growth products, picketing publishers and newspapers that use $\mathrm{BC}$ paper, and boarding ships carrying $\mathrm{BC}$ forest products. In Europe, anti-logging groups trucked around "Stumpy" - a large "old-growth" stump from BC - a simple, effective image implying ecological devastation of old-growth forests (but avoiding addressing any of the nuances). This technique had been perfected through the anti-sealing campaigns which featured blow-up plastic "baby" seals, and bloodied clubwielding sealers - enacting eye-catching, if inaccurate scenes in Trafalgar Square and other European arenas for horrified and outraged urban audiences. Inflatable bears were also used in Europe, making eye-catching impressions regarding the NGO-created concept of the "Great Bear Rainforest"
(Beatty 1999). From abroad, influence has been exerted through market and consumer campaigns. The Rainforest Action Network targeted Home Depot, a huge US retailer of lumber. They also trained companies in Europe and the US, anxious to please their European consumers, to ask BC suppliers "What are you doing about certification? Why are you not doing what MacMillan Bloedel has done?" (T. Tevlin, President, Forest Alliance of BC, Vancouver, personal communication, 1999). Ironically, it appears that many of the retailers now demanding certified products are not doing so in response to customer demand, but in reaction to pressures from environmental groups (Clark 2000).

The focus of many of these campaigns has been the practice of clearcutting; unfortunately, the campaigns and their authors do not distinguish between coastal and interior forests, or between different forest types, which can be very different ecosystems. Coastal forests do indeed grow very old, and may be more adapted to small-scale perturbations; interior forests, on the other hand, do not grow to such age, and tend to be destroyed by largescale fires or pests every 100 to 200 years, with the result that they may be more adapted to large-scale harvesting. Thus, the ecological information that the campaigns are based upon is poor, and not very appropriate for meaningful management of forests. Certainly, the coastal forests may benefit from reduced clearcutting, but is this prescription valid for interior and other forests? Truthfully, like the anti-fur campaign, this one is not really about the extinction or endangerment of species or populations, but about stopping a practice that is ugly, or culturally unfamiliar.

The campaigns in Europe and the US against BC oldgrowth products have used a market-based approach to convince industry that it is in its own best financial interest to address concerns about forest practices. They have been able to convince MacMillan Bloedel, Western Forest Products, Lignum and Canfor to announce an intention to seek eco-certification of their products by the Forest Stewardship Council, Canadian Standards Association, and the International Standards Organization.

MacMillan Bloedel (now Weyerhaeuser) has also announced it will phase out clearcuts within five years, and move to more cooperative relationships with NGOs, and in the spring of 2000 , MacBlo with several other companies announced a halt to logging in the "Great Bear Rainforest" while they negotiated options with NGOs. Interestingly, some industry concerns about the MacBlo move to reduce clearcutting are that it is uneconomic, environmentally unsound, and unsafe for forest workers, the latter concern reminiscent of the concern over new, "humane" but human-dangerous traps.

In addition, campaigners have focussed on retailers and other industrial customers of the $\mathrm{BC}$ forest industry. This has been effective, in that international retailers demanding certified products do so not because of customer requests, but to appease NGOs (Ford 2000). Tactics verging on blackmail have been used to force companies to take action (Fig. 1).

Interestingly, Greenpeace and the Coastal Rainforest Coalition ran an in the New York Times, on December 8, 1998, naming IBM and 26 other companies as leading the way in protection of rain forests because they were no longer buying $\mathrm{BC}$ old-growth products. Significantly, the CEO of IBM replied within short order, in a letter to customers and others, which was printed in newspapers as well, that they do indeed use $95 \%$ 
"We respectfully encourage your company to do the following: ...

1) Completely phase out all purchases from old growth forests. ...

2) Increase sales of solid wood products from second growth forests that are certified by the Forest Stewardship Council.

... if your company refuses to make this commitment, our alliance of environmental organizations will launch a public campaign in early October 1999, the purpose of which will be to inform your customers and shareholders of your continued inaction."

(Source: Clark 2000)

Fig. 1. Letter from Rainforest Action Network.

recycled paper in their publications - to encourage conservation of old growth and temperate rain forests, but that they do purchase old-growth products where they are being managed in iecologically sound and sustainable ways. IBM recognized the הisignificant steps BC has taken to preserve old growth and temOperate rain forest, and did NOT approve of the ad put out by SGreenpeace et al. and was not, furthermore, participating in nany boycotts (Wetmore 1998).

In Canadian terms, as with the sealing issue, the public sentiment in $\mathrm{BC}$ is not against logging and forestry activities, though re is some sign of increasing concern on some fronts, as illusted by some surveys conducted in BC in 1991 and 1998 able 1). Concerns over clearcutting and old-growth logging Ive increased somewhat, probably reflecting public envinmental campaigns, while fewer people are concerned out reforestation, possibly reflecting more visible reforestation ograms in recent years. There is very little change in the numer concerned about overcutting and an increase in those concerned about jobs.

Another series of MarkTrend surveys from November 1989 to May 1994 suggests that the public is becoming critical of environmental groups as well. The surveys illustrate rela.O tive public regard for BC's forest industry and environmental groups, in terms of the degree of responsibility they show to the province of $\mathrm{BC}$ as a whole. Environmental groups started with $79 \%$ support in 1989 , while the forest industry had 40\%; in November 1993, they held equal positions, and by May б1994, environmental groups had $49 \%$ support while the forest industry had $60 \%$. The relative positions of each group have switched back and forth several times since then; in June 1998, they were almost even at $58 \%$ and $61 \%$ respectively (T. Tevlin, President, Forest Alliance of BC, Vancouver, personal communication).

It seems that by and large, the public in $\mathrm{BC}$ supports the forestry activities, even though it might be influenced at times by environmental campaigns. Like NWT residents, BC residents continue to rely on, and support resource-based economic activities, though they want to see them conducted in a sustainable manner. However, critics from outside the province, as well as inside, still question the validity of logging. Their growing power and influence, and their ability to disembowel a region's economy, mean that their concerns and tactics must be recognized.
Table 1. Changing percentage of respondents' concerns over some BC forest industry practices

\begin{tabular}{lcc}
\hline & August 1991 & December 1998 \\
\hline Clearcutting & $12 \%$ & $19 \%$ \\
old-growth logging & $2 \%$ & $7 \%$ \\
lack of reforestation & $21 \%$ & $12 \%$ \\
Overcutting & $10 \%$ & $11 \%$ \\
jobs in forest industry & $3 \%$ & $5 \%$ \\
\hline
\end{tabular}

Source: MarkTrend Research (Dec. 1998) 7 .

\section{Comparing the Anti-Trapping and Anti-Logging Campaigns}

The anti-trapping campaign suggests some useful lessons for those dealing with the anti-logging campaign. Table 2 compares the key aspects of each of these campaigns. The former was aimed at government regulation and prohibitions of trapping, as well as consumer tastes, whereas the latter is aimed more at diverting consumers and companies from buying $\mathrm{BC}$ forest products. In both cases, information campaigns were aimed at changing public attitudes and urging consumer boycotts, whether individual or corporate. Markets are coming to be seen as the most effective way to exert control over resource use and policy; campaigns portray the targeted resource use as cruel, ignorant, frivolous, destructive, stupid and so on.

Campaigns may appear to be driven by ecological arguments, but these do not necessarily hold water. It did not matter that populations of fur-bearers and seals were (and are) very healthy and carefully managed. In the BC forestry context, fuzzy terms like "old-growth," "clearcuts," and "protecting biodiversity," and a lack of differentiation between forest types have clouded any real discussion of ecologically-appropriate forest management (D. Morrell, International Section, Ministry of Forests, Victoria, personal communication). The real issue is more one of image. Clearcuts look ugly, and are therefore always assumed to be destructive. Such generalizations start to serve a mantra-like purpose: "all trapping is inhumane," "all clearcutting is ecologically devastating."

In the anti-harvest campaigns, a catch phrase rapidly replaces detailed arguments - "steel-jawed leg-hold traps" for instance, a term that was not even quite correct in many situations, but which was certainly vivid. The unofficial creation of the "Great Bear Rainforest" by ENGOs was essentially a marketing tool, useful in raising donations. More spiritual than ecological in foundation, the concept was investigated as a way for anti-logging groups to designate their next region of focus. The term has invented a powerful web of images that is hard to deal with in any meaningful and concrete way. This is frustrating for resource managers who understand the nuances of an argument, but it is a key technique of advertising and creating sound bites for fund-raising purposes.

Another "fuzziness" in the arguments, which works against finding realistic solutions to resource issues, is that the interests of people and economies are seldom part of the story. This is a betrayal of the concept of sustainable development, introduced by Brundtland in 1987 and negotiated into all facets of

${ }^{7}$ Based on 504 random sample telephone interviews in BC. 
Table 2. Comparison of anti-fur and anti-logging campaigns

\begin{tabular}{ll}
\hline Anti-fur campaigns - NWT & Anti-logging campaigns - BC \\
\hline Resource use is vital to community & Forestry contributes a major \\
survival: traditional, cultural and & portion of many BC communities' \\
economic values & $\begin{array}{l}\text { livelihoods, and a significant part } \\
\text { of government revenues }\end{array}$
\end{tabular}

Most of public supports seal hunting/ trapping as long as it is sustainable

Oscillating support for environmental groups and forest industry

Powerful images: "steel-jawed leghold trap" and cruel "baby" seal killers

Ecological argument is not the key; neither seals nor fur-bearers were endangered

Serious impacts of the campaign on resource-based communities

Federal government reluctant to engage in the fight, though did so latterly - territorial/provincial governments did much of it

\section{GNWT/FIC response: \\ - educate Europeans \\ - R\&D - develop better traps - educate/help trappers}

Standards are a moving target; the objective of some parties is not compromise

Europeans don't follow their own rules - "pest" trapping

NGOs increasingly involved in decision-making

Cooperative agreements can be effective

Species-by-species framework agreement makes compliance easier
Ecological information has been wrong, simplistic or misleading; different forest ecosystems are not reflected

Companies have lost sales

International Forestry Partnership Program (fed/prov/ industry); dedicated financial resources

\section{BC Government/Forest Alliance response: \\ - visits/ lobbying of consumers \\ - develop better management processes i.e., FPC \\ - need to educate about value- added, ecocertification, ways to meet new values}

Terms are fuzzy i.e., "old growth," "clearcuts"; will certification correct this?

Little "old-growth" in Europe; second growth forests are all that remain; extensive plantations, but they do not preserve biodiversity

Forest Stewardship Council and others have increasing role

Would multi-lateral agreements re: forests or certification be effective?

Specifics of forest type/ecotype should direct agreements

states' policy during the United Nations Conference on Environment and Development in Rio de Janeiro in 1992. Sustainable development comprises the three legs of ecology, society and economy, and without each of those legs being strong, the "stool" will fall. If people are removed from a viable living, how can they maintain their social community, or their local economy, and how can they protect the environment? It is increasingly being recognized that efforts to conserve wildlife, fishery and other resources, without considering the traditional relationships of local people with those species, are likely to cause even greater problems (UNCED 1992, Edwards 1995, Freeman 1997). Indeed, the recent negotiations about the Great Bear Rainforest have

faltered because their NGO-industry focus has excluded a num ber of stakeholders until recently, notably First Nations, com munities and workers, who feel that they should be include in any planning or agreement.

From the North, the campaigns against resource harvestin are often seen as representing the interests of rich, urban, well fed people, who have destroyed their own immediate environmen and now want to save others, and who have a secure livelihooc but do not understand that other people do not. Too late Greenpeace acknowledged the social devastation that it campaigns had wrought on Inuit communities, and issued a apology, but Lynx and the International Fund for Animal Wel fare never have. There is also little sign that the lesson has bee applied to other campaigns; there seems to be very littl recognition that people are part of the landscape, along wit ecological and economic values.

The NWT experience shows that it is useful to fight fire wit fire - that is, (mis)information campaign with information. $\mathrm{Bv}$ this has to be concerted and continued. First-hand exposure like taking parliamentarians to trappers' cabins is powerfu] but cannot reach everyone - ways have to be found to take th information to a broader audience too. Other means of gettin: the message out to European audiences have been tried by var ious organizations - personal lobbying of European politician by native representatives; development of museum and galler. exhibitions of the northern/native/hunter/trapper reality books and TV programs. Exhausting as it can be, it seems tha this information has to be put out continually; the anti-harves campaigns come around again and again - it is not enough $t_{1}$ think that the end of one means that northerners can get on wit their lives.

There is one major difference between the responses to th anti-fur campaigns and the anti-logging campaigns; wherea the federal government was sometimes uncertain about its com mitment to helping with the former, it seems to have clearl: committed to helping with the latter, through the formation ani funding of the International Forestry Partnership Program, whicl involves federal, provincial and industry partners. As in th anti-fur response, an industry group is also taking concerter action - the Forest Alliance, like the Fur Council of Canada facilitates visits to Canada for European representatives, lob bying in Europe, information campaigns and other activitie (T. Tevlin, President, Forest Alliance of BC, Vancouver personal communication).

Environmental groups are increasingly included in internationa decision-making processes - whether overtly or covertly They have a lot of income (and expenses) riding on success ful conclusions to the issues they are involved with. Observer of international processes such as the International Whalini Commission or the Convention on International Trade is Endangered Species report that wealthy NGOs have been abl to influence the votes of poorer countries, often uninvolver in the issue, but attending the international meeting (Freemal 1990). Thus, we find that, despite the ostensible goals of a pro cess or committee, such as the humane standards committees or the International Whaling Commission ${ }^{7}$, the objective o some parties may not even include finding a compromise. A

\footnotetext{
${ }^{8}$ The IWC's mandate is to manage whaling, not to stop it, but infiltration b NGOs has directed discussions towards moratoria, despite scientific finding about the health of some whale populations.
} 
certification of forest products proceeds, parties to the process must deal with these kinds of tactics.

Strong environmental positions are embedded in the European governments, regardless of the feelings of their citizens. The internal committees of the European Parliament are powerful, and committed to their understanding of issues, be they trapping or clearcutting. Ironically, they do not seem to be in tune with their publics, who comprise $75 \%$ of the fur markets in the world. Likewise, it is not customer demand that is driving retailers to demand certified wood products, but NGO pressure affecting corporate image. Public support for a sustainable harvest of seals, furs or trees must be highlighted and brought to governments' attention.

Perhaps most jarring, European countries do not necessarily follow their own rules - they use leg-hold traps themselves, undertake clearcut logging, and plant massive monoculture plantations of trees for forestry that are biodiversity wastelands. It is an ironic continuation of imperialism that England, which was $90 \%$ deforested by the 12 th century and has never recovered much of its topsoil and forest cover, should be dictating forest practices to other parts of the world from a moral high-ground.

The experience from the response to the latest anti-trapping move shows that international cooperation among producing countries or producing and consuming countries can be effective in achieving agreements. Furthermore, the fur boycott resolution shows that breaking regulations down so as to deal with component parts - for instance, species by species - can make the regulations more sensible, realistic, implementable, כand easier to deal with - and perhaps truer to the relevant sciop a sweeping definition of what is sustainable forestry when dealing with the diversity of forests that we have in $\mathrm{BC}$, let alone the rest of the world.

The experience of the fur industry also shows pretty clearly that some adaptation by resource users is perhaps inevitable in the face of new social/environmental movements and changing social values. On the other hand, such adaptation can also be used as a bargaining tool. The existence of the Vegreville testing facility and the research that had been done on humane trap standards stood in Canada's favour when it came to negotiating the agreement with the EC. In BC, the establishment of the Forest Practices Code was clearly a response to the perceived and anticipated pressures from Europe and the USA. Proven improvements in forest management achieved through such mechanisms as the Protected Areas Strategy, Land and Resource Management Planning Process and other initiatives could strengthen the argument that $\mathrm{BC}$ is managing its forests for sustainable use. The increasing interest in eco-certification among $\mathrm{BC}$ wood producers indicates that this type of thinking is beginning to occur here.

\section{What Should the BC Forest Industry and Government Be Doing?}

The spotlight is on $\mathrm{BC}$ regarding sustainable logging, and the province will have to deal with public scrutiny that affects its markets. As our society's demographics and associated values change, these pressures may increase. While public scrutiny of practices can be useful to ensure that resource use is conducted well and sustainably, it becomes a problem when intense political feelings are based on simplified, one-sided information. Such campaigns may successfully raise funds and public consciousness, but they are not helpful in finding practical, realistic solutions that serve the interests of all.

The analysis above suggests several things that can be done to respond to the increasing pressures on $\mathrm{BC}$ forestry.

$\mathrm{BC}$ and its forestry communities must acknowledge changing social values and respond to them, trying to understand their underlying causes. This will be reflected in the form of more meaningful public involvement, greater inclusion of nontimber values in forest management, concern for community survival, and for environment and wilderness. If the world economy is turning away from natural resources as Angus Reid predicts (1997), the other values inherent in the forests will become even more important. But at the same time, we need to seize the moral high ground, and argue for the appreciation of regional diversity and the appropriateness of regionally adapted cultures and resource uses.

BC must fight fire with fire - (mis)-information campaigns with information campaigns. This needs to be aimed at a variety of audiences - consumers, governments, advocacy groups, media, environmental groups, and similar interest groups, both here and in other countries. Indigenous Survival International and now Forest Alliance have found that in order to deal with NGO lobbying of companies and consumers in Europe and the US, one must be there as well, with more precise, honest, useful information.

It will likely be a long fight, with sporadic, reoccurring campaigns. Given the demographic changes occurring, we can expect increasing concerns for the environment, access to wilderness and rural lifestyles. The anti-fur campaigns have re-surfaced several times in the North - one round of responses was not enough. One of the tactics seems to be repeated assaults - perhaps hoping to induce exhaustion.

The forest industry must be pro-active, developing its own strategies to meet stricter regulations and fussier markets. Forest Certification could be a positive way for $\mathrm{BC}$ companies to prove their sustainability and appears to be being embraced by many. It will also help to make the case for BC forestry if the government and industry can show that they are doing effective $R \& D$, improving utilization of forest resources, diversifying uses, and ensuring community relevance. However, as the trappers' experience also showed, achieving "certification" is worthless if the goal posts are then just to be moved: hopefully, the eco-certification process for forestry will avoid this.

The BC industry, and professional foresters need to be "out there" engaging in honest, critical, scientific discussions about the advantages of forestry, how it can be or is done well or could be done better, and how it meets the values of biodiversity conservation, how biodiversity targets are determined and met, socioeconomic development and so on. Processes like the Kyoto Convention can be used to advocate forestry use and reforestation (P. Moore, Speech to the Consulting Foresters, Assoc. of BC Professional Foresters' AGM, Feb. $19,1999)$. BC foresters need to be part of the global discussions about how to achieve sustainable development. Further, the $\mathrm{BC}$ government needs a team dedicated to full-time international work on the issue of biodiversity and sustainable development. At present the Minister or Chief Forester makes a few visits annually to Europe, but this is not sufficient to meet the demands for information.

The environmental NGOs must be engaged in knowledgeable, honest discussion too, with pressure kept on them 
to be precise and accurate in their information. This is an indispensable contributor to the key ingredient in conflict resolutions - trust. The NGOs connect to the concerns of a significant portion of the population, but they are also under pressure to mount visible campaigns and bring in funding. They should also be pressured not just to identify "problems," but to contribute to solutions (which is much more difficult and less newsworthy). Along with this clear, honest engagement must go some pressure to be fair members of processes - for instance, not bailing out when it looks like a solution is at hand.

Perhaps the most important lesson from the European trapping negotiations is that breaking the discussion of issues and solutions down into more precise elements will make eventual arrangements both more credible and meaningful, as with the species-by-species Framework Agreement developed regarding furs. The European trapping resolution also suggests the utility of developing multilateral agreements, which more precisely reflect the issues and realities of their parties.

Fundamentally, we must call the Europeans and Americans on their own behaviour; why is wild-trapping in Canada bad, while fur-ranching and pest-trapping in Europe are good? Why is forestry in $\mathrm{BC}$ wild forests worse than in sterile plantations in Europe? What is at issue, fundamentally, is respect for regional differences, and for different cultures and their relationships to resources.

\section{References}

Ames, R. et al. 1988. Keeping on the land: a study of the feasability of a comprehensive wildlife harvest support programme in the Northwest Territories. Canadian Arctic Resources Committee, Ottawa.

Beatty, J. 1999. Time Magazine calls Great Bear Rain Forest deal top achievement. Vancouver Sun, Dec. 23.

Canada, House of Commons. 1993. Canada fur watch: aboriginal livelihood at risk. Fifth report of the Standing Committee on Aboriginal Affairs. Cited in Maracle, R. n.d. Impacts of the European Union (EU) regulation $3254 / 91$ on the aboriginal peoples of Canada. http://www.inac.gc.ca/pr/pub/rprt_e.html

Clark, R. 2000. Sustainable Forestry and Certification Watch. The B.C. Forest certification Forum, sponsored by Ecoforestry Institute, March 30 - April 1, 2000, Victoria, BC.

Edwards, S.R. 1995. Conserving biodiversity: resources for our future. In R. Bailey (ed.). The true state of the planet. pp. 211-265. The Free Press, New York.
Elias, P.D. 1993. A framework for understanding northern economies. Faculty of Management, University of Lethbridge, Lethbridge, Alberta.

Fast, H. and F. Berkes. 1994. Native land use, traditional knowledge and the subsistence economy in the Hudson Bay Bioregion. Natural Resources Institute, Winnipeg, University of Manitoba.

Ford, D. 2000. Perspectives on Forest Certification. The B.C. Forest Certification Forum, sponsored by Ecoforestry Institute, March 30 - April 1, 2000, Victoria, BC.

Freeman, M.M.R., 1990. A commentary on political issues with regard to contemporary whaling, N. Atlantic Studies 2(1-2): 106-116.

Freeman, M.M.R. 1997. Issues affecting subsistence security in arctic societies. Arctic Anthropology. 34(1): 7-17.

Habib, M. 1997. Fur once again flying out retailers' doors: Canadian designers front and centre on the runways in an industry on the upswing. (The Canadian Press) The Prince George Citizen, Nov. 28. Hunter, J. 1998. MacBlo to end clearcutting in old-growth coast forests. Vancouver Sun, June 10.

Inuit Circumpolar Conference. 1996. The arctic sealing industry: a retrospective analysis of its collapse and options for sustainable development. Part I. Retrospective analysis.

Lynge, F. 1992. Arctic wars: animal rights, endangered peoples. University Press of New England, Hanover.

Maracle, R. n.d. Impacts of the European Union (EU) regulation 3254/91 on the aboriginal peoples of Canada. http://www.inac.gc.ca/pubs/ report.html.

Nunatsiaq News. 1997. Animal rights fascism. Oct. 10.

Reid, A. 1997. Shakedown: how the new economy is changing our lives. Seal Books, Toronto, ON.

Stoett, P.J. 1997. The international politics of whaling. UBC Press, Vancouver.

United Nations Conference on Environment and Development (UNCED). 1992. Agenda 21, United Nations, New York.

Usher, P.J. 1981. Sustenance or recreation? The future of native wildlife harvesting in Northern Canada. In M.M.R. Freeman (ed.). Proceedings: The First International Symposium on Renewable Resources and the economy of the North. Association of Canadian Universities for Northern Studies, and Canada-MAB Programme, Ottawa.

Wenzel, G.W. 1991. Animal rights, human rights: ecology, economy and ideology in the Canadian arctic. Belhaven, London.

Wetmore, J. 1998. In "IBM 'did not approve' Rainforest ad." Prince George Citizen, Dec. 16. 